\title{
RADIOECOLOGICAL INVESTIGATION IN THE ENVIRONMENT OF BELGRADE CITY, SERBIA*
}

\author{
Branislava Mitrović ${ }^{1^{* *}}$, Svetlana Grdović1, Borjana Vranješ ${ }^{1}$, \\ Mihajlo Vićentijević ${ }^{2}$, Jelena Ajtić1, Darko Sarvan' \\ ${ }^{1}$ Faculty of Veterinary Medicine, University of Belgrade, Belgrade, Serbia \\ ${ }^{2}$ Science Institute of Veterinary Medicine of Serbia, Belgrade, Serbia
}

\begin{abstract}
Activity concentrations of ${ }^{40} \mathrm{~K},{ }^{238} \mathrm{U},{ }^{232} \mathrm{Th}$ and ${ }^{137} \mathrm{Cs}$ in the samples of cultivated and uncultivated soil, mosses, mushrooms and game meat (wild rabbit, pheasant and wild boar) are measured by the gamma spectrometry technique. The samples were collected in suburban areas of Belgrade, Serbia, in the period from 2008-2014. The mean activity concentrations of ${ }^{40} \mathrm{~K},{ }^{238} \mathrm{U}$ and ${ }^{232} \mathrm{Th}$ in cultivated soil are $637 \mathrm{~Bq} \cdot \mathrm{kg}^{-1}, 52 \mathrm{~Bq} \cdot \mathrm{kg}^{-1}$ and $53 \mathrm{~Bq} \cdot \mathrm{kg}^{-1}$, and in

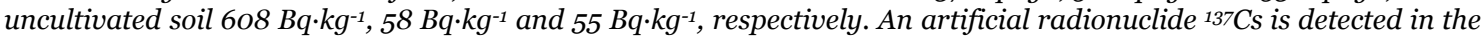
samples of soil, mosses and mushrooms, which indicates that almost 30 years after the nuclear accident in Chernobyl, ${ }^{137}$ Cs is still present in the environment. Since the activity concentrations of primordial radionuclides and ${ }^{137 C s}$ in game meat are below detection limit, these samples can be classified as safe for consumption.
\end{abstract}

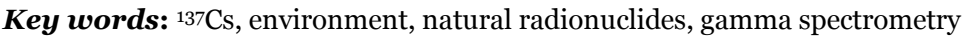

\section{INTRODUCTION}

Naturally occurring radionuclides in the environment represent the main source of radiation exposure for humans and biota. Various applications of nuclear energy, the use of depleted uranium in ammunition, coal combustion, mining industry and the formation of radioactive waste dumps are activities that contribute to the redistribution of natural radioactivity. One of the most important factors in the environmental pollution with ${ }^{238} \mathrm{U}$ is the production and application of phosphorus fertilizers [1]. In the soil, uranium from fertilizers is frequently in the form which is easily available to plants, resulting in a higher possibility for uranium incorporation in the food chain [2]-[4].

After the nuclear accident in Chernobyl in 1986, an increased level of radioactive cesium was detected in the environment. Numerous studies have shown that mosses, lichens and mushrooms are typical representatives of bioindicator plants, showing the presence of radiocesium and natural radionuclides in the environment [5]-[10]. Due to their anatomical, morphological and physiological characteristics, mosses are capable of accumulating pollutants from aero sediments, radionuclides and pollutants from the soil. Mosses are good bioindicators for a number of reasons: they have a wide ecological and geological distribution; they are present over the whole year (in most cases, they are perennials); they have a high degree of tolerance to pollutants; the absorption of mineral matter is done by the whole body surface, since mosses have no cuticle or stomas on the leaves; their accumulating capacity is higher than of other plants [11], [12]; their ability to indicate quality of the air, water and soil, resulting from their presence, absence or floristic composition, is an important characteristic and facilitates their use as bioindicators of radioactive contamination [10]; and mosses entrap airborne particulates, both passively and actively, through an extracellular ion exchange [13].

Meat of wild animals is also considered to be a good indicator of radioactive contamination in the

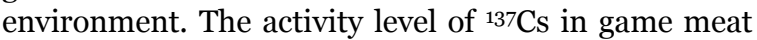
before and after the Chernobyl accident was investigated [14], and a significant increase in radiocesium activity was found.

Sample selection is an important factor in radiological investigations in a certain area. In our study, cultivated and uncultivated soil, mosses, mushrooms, meat of wild rabbits, pheasants and wild boars, were sampled in several locations in Belgrade. Agricultural activities are undertaken in these sampling sites, and the sites are also used for sport hunting.

\section{MATERIALS AND METHODS}

Over the 2008-2014 period, the samples of cultivated and uncultivated soil, mosses, mushrooms, meat of wild rabbits, pheasants and wild boars were collected in eight suburban areas of Belgrade, the capital of the Republic of Serbia, with an intensive agricultural production: Avala-Zuce, KosmajNemenikuće, Barajevo, Grocka-Vinča, Opovo, SurčinBojčin forest, Lazarevac-Vreoci, and ObrenovacKonatica (Figure 1). These sampling sites were selected on the grounds that they present significant arable land used for food (and feed) production for the Belgrade population. Further, there are differences among the sites which could contribute to different activity concentrations of the selected radionuclides. 
B. Mitrović et al., Radioecological Investigation..., Rad. Applic., 2016, 1, 3, 199-203

For example, Avala (511 m a.s.l.) and Kosmaj (629 m a.s.l.) are mountainous areas in the vicinity of the city. The Grocka-Vinča site, on the other hand, is located near the Institute of Nuclear Sciences "Vinča" and this investigation could indicate a possible impact of former and present nuclear activities on the surrounding environment. An installation for coal processing (washing, drying, etc.) and coal power plants are located in the areas of Lazarevac and Obrenovac, so these two sampling sites could offer an insight into a possible influence of coal use on the immediate environment.

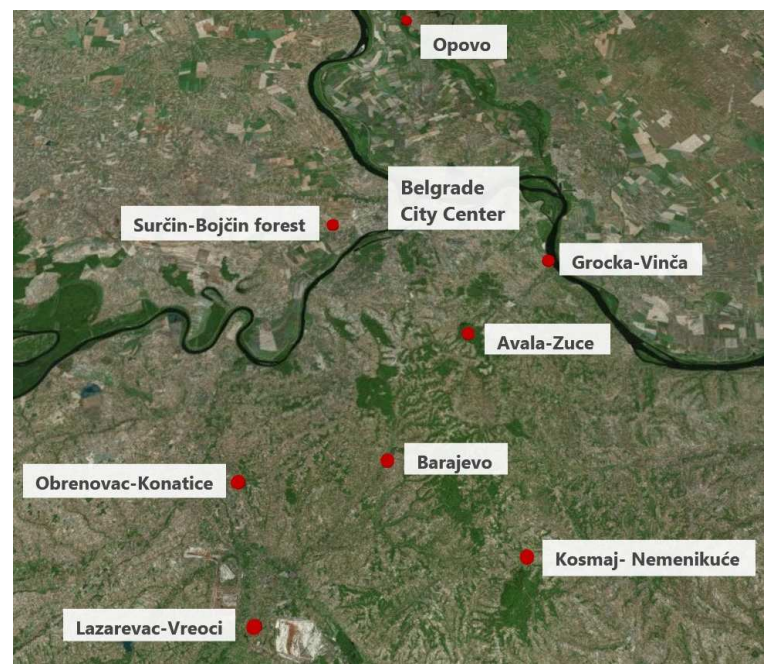

Figure 1. Sampling sites in Belgrade

The soil samples, with a mass of $3-5 \mathrm{~kg}$, were collected from a depth of $0-10 \mathrm{~cm}$, homogenized, dried at a temperature of $105{ }^{\circ} \mathrm{C}$, and stored in $1 \mathrm{l}$ Marinelli beakers. The moss samples, with a mass of $2 \mathrm{~kg}$ in fresh form, were collected from stones and tree barks. They were firstly cleaned from soil and other impurities, and then dried at a temperature of $80^{\circ} \mathrm{C}$ until constant mass. The samples were ground and packed in $200 \mathrm{ml}$ plastic vessels. The moss samples consisted of a mixture of moss species. The mushroom samples were prepared in the same manner. The wild animal meat samples (rabbits, pheasants and wild boars) were homogenized and measured into $1 \mathrm{l}$ Marinelli beakers.

All homogenized samples were sealed tightly and kept for 40 days to ensure that equilibrium between ${ }^{226} \mathrm{Ra}$ and its short-lived decay products was reached.

Content of the investigated radionuclides in the samples was determined by gamma spectro-metry on a High Purity Germanium detector (Ortec, USA) with a relative efficiency of $30 \%$ and the energy resolution of $1.85 \mathrm{keV}\left(1332.5 \mathrm{keV}{ }^{60} \mathrm{Co}\right)$. The analysis of the measured gamma spectra was performed by a software program GAMMA VISION $\AA 32$ (Ortec, USA). The detector efficiency calibration was performed for different geometries and different matrices, in accordance with the measured sample type.

We used commercially available standards with mixed radionuclides:

${ }^{241} \mathrm{Am},{ }^{133} \mathrm{Ba},{ }^{109} \mathrm{Cd},{ }^{139} \mathrm{Ce},{ }^{57} \mathrm{Co},{ }^{60} \mathrm{Co},{ }^{137} \mathrm{Cs}$, ${ }^{54} \mathrm{Mn},{ }^{113 \mathrm{Sn}},{ }^{85 \mathrm{Sr}},{ }^{88} \mathrm{Y}$, dispersed in silicone resin in
Marinelli beaker, density $(0.98 \pm 0.01) \mathrm{g} \cdot \mathrm{cm}^{-3}$, volume 1 $\mathrm{l}$; and

- ${ }^{241} \mathrm{Am},{ }^{109} \mathrm{Cd},{ }^{139} \mathrm{Ce},{ }^{57} \mathrm{Co},{ }^{60} \mathrm{Co},{ }^{137} \mathrm{Cs},{ }^{113 \mathrm{Sn}}$, ${ }^{85} \mathrm{Sr},{ }^{88} \mathrm{Y}$, dispersed in silicone resin in Marinelli beaker, density $(1.22 \pm 0.01) \mathrm{g} \cdot \mathrm{cm}^{-3}$, volume $1 \mathrm{l}$.

The first calibration was used for meat measurements; the second for the soil measurements. The counting time was 60 ooo s for meat and soil, as for the background.

The system was calibrated for cylindrical geometry using certified reference materials IAEA-330 (spinach) and Moha Barna standard. The counting time for moss and mushrooms, as well as for the background, was $250000 \mathrm{~s}$.

The gamma spectrometric analysis of ${ }^{238} \mathrm{U}$ relies on the hypothesis of equilibrium between the parent nuclide ${ }^{238} \mathrm{U}$ and its daughters, ${ }^{234} \mathrm{Th}(63.2 \mathrm{keV})$ and ${ }^{234 \mathrm{mPa}}(1001 \mathrm{keV})$. In the case of ${ }^{232} \mathrm{Th}$, three photo peaks of ${ }^{228} \mathrm{Ac}(338,911.2$ and $969 \mathrm{keV})$ were used in the same way. The activities of ${ }^{\circ} \mathrm{K}$ and ${ }^{137 \mathrm{Cs}}$ were derived from $1460.8 \mathrm{keV}$ and $661.66 \mathrm{keV}$ gamma lines, respectively.

\section{RESULTS AND DISCUSSION}

The activity concentration of ${ }^{40} \mathrm{~K},{ }^{238} \mathrm{U},{ }^{232} \mathrm{Th}$ and ${ }^{137} \mathrm{Cs}$ measured in cultivated and uncultivated soil are shown in Table 1. The radio-nuclides' specific activities in mosses, seasonal mushrooms, meat of wild rabbits, pheasants and wild boars are given in Table 2. The results are expressed as "mean \pm standard deviation".

Table 1. Specific activity of the radionuclides in the soil $\left(\mathrm{Bq} \cdot \mathrm{kg}^{-1}\right)$

\begin{tabular}{|c|c|c|c|c|}
\hline Soil samples & $4^{40} \mathrm{~K}$ & $23^{8} \mathrm{U}$ & $23^{2} \mathrm{Th}$ & ${ }^{137} \mathrm{Cs}$ \\
\hline \multicolumn{5}{|c|}{ Avala-Zuce } \\
\hline cultivated & $650 \pm 16$ & $56 \pm 2$ & $56 \pm 3$ & $28 \pm 2$ \\
\hline uncultivated & $622 \pm 20$ & $44 \pm 4$ & $55 \pm 2$ & $98 \pm 3$ \\
\hline \multicolumn{5}{|c|}{ Kosmaj-Nemenikuće } \\
\hline cultivated & $594 \pm 18$ & $52 \pm 7$ & $62 \pm 3$ & $27 \pm 1$ \\
\hline uncultivated & $517 \pm 18$ & $62 \pm 7$ & $61 \pm 2$ & $31 \pm 1$ \\
\hline \multicolumn{5}{|c|}{ Barajevo } \\
\hline cultivated & $616 \pm 16$ & $54 \pm 8$ & $62 \pm 3$ & $47 \pm 2$ \\
\hline uncultivated & $548 \pm 16$ & $62 \pm 6$ & $56 \pm 2$ & $75 \pm 2$ \\
\hline \multicolumn{5}{|c|}{ Grocka-Vinča } \\
\hline cultivated & $676 \pm 19$ & $58 \pm 7$ & $47 \pm 3$ & $25^{ \pm 2}$ \\
\hline uncultivated & $632 \pm 19$ & $47 \pm 6$ & $55 \pm 2$ & $33 \pm 4$ \\
\hline \multicolumn{5}{|c|}{ Opovo } \\
\hline cultivated & $636 \pm 17$ & $51 \pm 6$ & $42 \pm 2$ & $19 \pm 1$ \\
\hline uncultivated & $612 \pm 18$ & $43 \pm 4$ & $41 \pm 1$ & $15 \pm 1$ \\
\hline \multicolumn{5}{|c|}{ Surčin-Bojčin forest } \\
\hline cultivated & $666 \pm 17$ & $50 \pm 5$ & $48 \pm 4$ & $22 \pm 1$ \\
\hline uncultivated & $695 \pm 22$ & $54 \pm 6$ & $50 \pm 2$ & $17 \pm 1$ \\
\hline \multicolumn{5}{|c|}{ Obrenovac-Konatice } \\
\hline cultivated & $667 \pm 19$ & $46 \pm 4$ & $51 \pm 3$ & $21 \pm 1$ \\
\hline uncultivated & $650 \pm 19$ & $56 \pm 3$ & $55 \pm 2$ & $43 \pm 1$ \\
\hline \multicolumn{5}{|c|}{ Lazarevac-Vreoci } \\
\hline cultivated & $588 \pm 18$ & $46 \pm 7$ & $53 \pm 2$ & $26 \pm 1$ \\
\hline uncultivated & $587 \pm 22$ & $95 \pm 5$ & $69 \pm 2$ & $23 \pm 1$ \\
\hline
\end{tabular}

The content of the natural ${ }^{\circ} \mathrm{K}$ in cultivated and uncultivated soil showed that the use of mineral fertilizers and the activities in a power plant (site 
Obrenovac) did not result in an increased $4^{\circ} \mathrm{K}$ content in the soil (Table 1). On the other hand, the uncultivated soil in the area of Lazarevac-Vreoci, close to an installation for coal processing, showed higher specific activities of ${ }^{238} \mathrm{U}$ and ${ }^{232} \mathrm{Th}$, which may be due to the dust deposition on the soil surface.

The mean activity concentrations (for all sites) of ${ }^{40} \mathrm{~K},{ }^{238} \mathrm{U}$ and ${ }^{232} \mathrm{Th}$ in cultivated soil were $637 \mathrm{~Bq} \cdot \mathrm{kg}^{-1}$, $52 \mathrm{~Bq} \cdot \mathrm{kg}^{-1}$ and $53 \mathrm{~Bq} \cdot \mathrm{kg}^{-1}$, and in uncultivated soil 608 $\mathrm{Bq} \cdot \mathrm{kg}^{-1}, 58 \mathrm{~Bq} \cdot \mathrm{kg}^{-1}$ and $55 \mathrm{~Bq} \cdot \mathrm{kg}^{-1}$, respectively. These findings are similar to the results obtained for the region of Vojvodina in northern Serbia [15], but are higher than the global average of $400 \mathrm{~Bq} \cdot \mathrm{kg}^{-1}$ for ${ }^{\circ} \mathrm{K}$, $35 \mathrm{~Bq} \cdot \mathrm{kg}^{-1}$ for ${ }^{238} \mathrm{U}$ and $30 \mathrm{~Bq} \cdot \mathrm{kg}^{-1}$ for ${ }^{232} \mathrm{Th}$ [16]. A lower content of natural radionuclides was detected in the soil from Čačak, a town located in the western part of central Serbia: $434 \mathrm{~Bq} \cdot \mathrm{kg}^{-1}$ of ${ }^{\circ} \mathrm{K}, 47 \mathrm{~Bq} \cdot \mathrm{kg}^{-1}$ of ${ }^{238} \mathrm{U}$, and $35 \mathrm{~Bq} \cdot \mathrm{kg}^{-1}$ of ${ }^{232} \mathrm{Th}$ [17]. These differences in the soil content are, to some extent, a consequence of the variety of geological structures in the investigated area caused by complex geotectonic processes.

The artificial radionuclide ${ }^{137 \mathrm{Cs}}$ was detected in both types of the soil. Before the Chernobyl accident in 1986, the specific activity of ${ }^{137 C s}$ in the soils of Serbia was less than $5 \mathrm{~Bq} \cdot \mathrm{kg}^{-1}$, and in most plants, except mosses and lichens, cesium was not detectable [18]. Following the accident, the cumulative depositions of ${ }^{134} \mathrm{Cs}$ and ${ }^{137} \mathrm{Cs}$ in the soil in Belgrade, were $4400 \mathrm{kBq} \cdot \mathrm{m}^{-2}$ and $8900 \mathrm{kBq} \cdot \mathrm{m}^{-2}$, respectively [19]. Our study showed that almost thirty years after the Chernobyl nuclear accident, radiocesium was still present in Serbia. The activity concentration of ${ }^{137 \mathrm{Cs}}$ was $19-47 \mathrm{~Bq} \cdot \mathrm{kg}^{-1}$ in cultivated soil, and $15-98 \mathrm{~Bq} \cdot \mathrm{kg}^{-1}$ in uncultivated soil. The highest ${ }^{137} \mathrm{Cs}$ activity concentration was detected in the uncultivated soil from Zuce (Avala Mountain), which could be due to an increased altitude [9]. These results confirm that agrotechnical procedures, such as ploughing and manuring, can reduce the ${ }^{137 \mathrm{Cs}}$ concentration in the soil [20]. The results for the Čačak area showed the

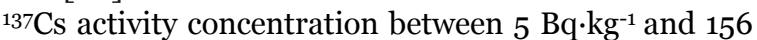
$\mathrm{Bq} \cdot \mathrm{kg}^{-1}$, with the mean of $43 \mathrm{~Bq} \cdot \mathrm{kg}^{-1}$ [17].

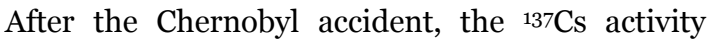
concentration in different regions of ex-Yugoslavia ranged from around $900 \mathrm{~Bq} \cdot \mathrm{kg}^{-1}$ to about $5000 \mathrm{~Bq} \cdot \mathrm{kg}^{-1}$, depending on the region and elevation [19]. The activity levels of ${ }^{137} \mathrm{Cs}$ in mosses from the highlands of Serbia and Montenegro varied between few hundreds and few thousands $\mathrm{Bq} \cdot \mathrm{kg}^{-1}$ [7], and were not correlated with the type of substratum (tree bark or soil). In our study, the ${ }^{137} \mathrm{Cs}$ specific activity in the moss samples was ${ }^{15-153} \mathrm{~Bq} \cdot \mathrm{kg}^{-1}$. Natural radionuclides ${ }^{40} \mathrm{~K},{ }^{238} \mathrm{U}$ and ${ }^{232} \mathrm{Th}$ were detected in all moss samples and their activity concentrations were in agreement with previously published results [21]-[23].

The samples of mushrooms (edible and inedible) were collected in the forest hunting areas. In forest ecosystems, large game animals supplement their diet in autumn with mushrooms which can contribute to their contamination with radionuclides. The highest activity concentration of $137 \mathrm{Cs}$ was detected in mushrooms from Barajevo (27 $\left.\mathrm{Bq} \cdot \mathrm{kg}^{-1}\right)$. In other

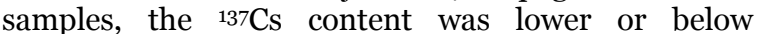
detection limits $\left(0.3^{-19} \mathrm{~Bq} \cdot \mathrm{kg}^{-1}\right)$. Although their consumption is not overly common in the nutrition of the human population in Serbia, mushrooms cannot be excluded as a part of the food chain in the environment. The activity concentration of ${ }^{40} \mathrm{~K}$ was 111-790 Bq. $\mathrm{kg}^{-1}$, while content of ${ }^{238} \mathrm{U}$ and ${ }^{232} \mathrm{Th}$ was below the detection limits.

Rabbits are herbivores that feed by grazing on grass, forbs and leafy weeds. After the Chernobyl accident, a high radiocontamination with ${ }^{134,137 \mathrm{Cs} \text { was }}$ observed in rabbit meat (average value was $900 \mathrm{~Bq} \cdot \mathrm{kg}$ 1) [24], which indicated rabbits as good bioindicators of radioactive contamination. Pheasants have a varied diet: they prefer grain fields, their nutrition is primarily herbal and consists of seeds, leaves, fruits, tubers and roots, but they also feed on insects, insect grubs, earthworms and even small reptiles. In the investigated samples of wild animal meat (wild rabbits, pheasants and wild boars), regardless of diet, low activities of both natural and artificial radionuclides were detected (Table 2 ).

Table 2. Specific activity of radionuclides in mosses, seasonal mushrooms, and wild animal meat $\left(\mathrm{Bq} \cdot \mathrm{kg}^{-1}\right)$

\begin{tabular}{|c|c|c|c|c|}
\hline Sample & ${ }^{40} \mathrm{~K}$ & ${ }^{238} \mathrm{U}$ & ${ }^{232} \mathrm{Th}$ & ${ }^{137} \mathrm{Cs}$ \\
\hline \multicolumn{5}{|c|}{ Avala-Zuce } \\
\hline $\operatorname{mosses}^{\mathrm{a}}$ & $174 \pm 10$ & $<36$ & $<27$ & $153 \pm 7$ \\
\hline mushrooms $^{\mathrm{a}}$ & $547 \pm 18$ & $<5$ & $<3$ & $19 \pm 2$ \\
\hline wild rabbit ${ }^{\mathrm{b}}$ & $64 \pm 4$ & $<1.3$ & $<0.2$ & $<0.1$ \\
\hline pheasant $^{\mathrm{b}}$ & $120 \pm 6$ & $3.5 \pm 0.3$ & $<0.4$ & $<0.1$ \\
\hline \multicolumn{5}{|c|}{ Kosmaj-Nemenikuće } \\
\hline mosses $^{\mathrm{a}}$ & $240 \pm 12$ & $44 \pm 9$ & $13 \pm 3$ & $68 \pm 6$ \\
\hline mushrooms $^{\mathrm{a}}$ & $276 \pm 4$ & $<4$ & $<1.6$ & $18 \pm 3$ \\
\hline wild rabbit ${ }^{\mathrm{b}}$ & $86 \pm 4$ & $1.6 \pm 0.3$ & $<0.3$ & $<0.1$ \\
\hline pheasant $^{\mathrm{b}}$ & $113 \pm 4$ & $<1.8$ & $<0.5$ & $<0.2$ \\
\hline wild boarb & $115 \pm 4$ & $<1.2$ & $<0.3$ & $<0.3$ \\
\hline \multicolumn{5}{|c|}{ Barajevo } \\
\hline $\operatorname{mosses}^{\mathrm{a}}$ & $238 \pm 16$ & $<18$ & $<16$ & $59 \pm 3$ \\
\hline mushrooms ${ }^{\mathrm{a}}$ & $790 \pm 22$ & $<3.5$ & $<2$ & $27 \pm 2$ \\
\hline wild rabbitb & $117 \pm 4$ & $<1.5$ & $<0.8$ & $<0.1$ \\
\hline pheasant $^{\mathrm{b}}$ & $125 \pm 5$ & $2.8 \pm 0.3$ & $<0.3$ & $<0.1$ \\
\hline wild boar ${ }^{b}$ & $77 \pm 3$ & $<1.1$ & $<0.2$ & 0.1 \\
\hline \multicolumn{5}{|c|}{ Grocka-Vinča } \\
\hline $\operatorname{mosses}^{\mathrm{a}}$ & $267 \pm 11$ & $44 \pm 7$ & $19 \pm 2$ & $43 \pm 4$ \\
\hline mushrooms $^{\mathrm{a}}$ & $338 \pm 8$ & $<6$ & $<1.2$ & $7 \pm 1$ \\
\hline wild rabbit ${ }^{b}$ & $99 \pm 3$ & $<1.3$ & $<0.2$ & $<0.1$ \\
\hline pheasant $^{\mathrm{b}}$ & $113 \pm 4$ & $<1.7$ & $<0.6$ & $<0.1$ \\
\hline \multicolumn{5}{|c|}{ Opovo } \\
\hline mosses $^{\mathrm{a}}$ & $429 \pm 17$ & $29 \pm 1$ & $30 \pm 4$ & $55 \pm 4$ \\
\hline mushrooms $^{\mathrm{a}}$ & $211 \pm 5$ & $<5.8$ & $<1.8$ & $9 \pm 2$ \\
\hline wild rabbit ${ }^{\mathrm{b}}$ & $117 \pm 4$ & $2.2 \pm 0.4$ & $0.3 \pm 0.1$ & $<0.2$ \\
\hline pheasant ${ }^{b}$ & $128 \pm 3$ & $<1.4$ & $<0.3$ & $<0.1$ \\
\hline \multicolumn{5}{|c|}{ Surčin -Bojčin forest } \\
\hline mosses $^{\mathrm{a}}$ & $259 \pm 13$ & $<24$ & $16 \pm 3$ & $15 \pm 1$ \\
\hline mushrooms ${ }^{\mathrm{a}}$ & $111 \pm 4$ & $<3.5$ & $<2.2$ & $<0.3$ \\
\hline wild rabbit ${ }^{b}$ & $92 \pm 5$ & $1.6 \pm 0.3$ & $<0.4$ & $<0.1$ \\
\hline pheasant $^{b}$ & $106 \pm 4$ & $<1.3$ & $<0.4$ & $<0.2$ \\
\hline \multicolumn{5}{|c|}{ Obrenovac-Konatice } \\
\hline mosses $^{a}$ & $130 \pm 6$ & $34 \pm 6$ & $32 \pm 8$ & $32 \pm 1$ \\
\hline wild rabbitb & $106 \pm 3$ & $<1.9$ & $<0.3$ & $<0.1$ \\
\hline pheasant $^{b}$ & $107 \pm 4$ & $<1.8$ & $<0.4$ & $<0.1$ \\
\hline \multicolumn{5}{|c|}{ Lazarevac-Vreoci } \\
\hline $\operatorname{mosses}^{\mathrm{a}}$ & $244 \pm 10$ & $24 \pm 1$ & $19 \pm 3$ & $104 \pm 9$ \\
\hline wild rabbitb & $62 \pm 3$ & $<1.3$ & $<0.3$ & $<0.1$ \\
\hline pheasant $^{b}$ & $95 \pm 4$ & $<0.5$ & $<0.3$ & $<0.1$ \\
\hline
\end{tabular}

a Dry weight; ${ }^{\mathrm{b}}$ Fresh weight 
4. CONCLUSION

Contents of natural and artificial radionuclides ${ }^{40} \mathrm{~K},{ }^{238} \mathrm{U},{ }^{232} \mathrm{Th}$, and ${ }^{137} \mathrm{Cs}$ in different environmental samples in Belgrade were measured. The results confirmed that mosses and mushrooms are very good bioindicators of radioactive pollution since the Chernobyl ${ }^{137}$ Cs was detected. ${ }^{137}$ Cs was not detected in the samples of wild animal meat, implying that this radionuclide is not incorporated significantly in the natural food chain.

The soil and moss samples were also collected from high-elevation sites in the Belgrade surroundings (Avala and Kosmaj), but there was no evident correlation between the site altitude and ${ }^{137 \mathrm{Cs} \text { specific }}$ activity in the soil. The specific activities of ${ }^{137} \mathrm{Cs}$ in both types of soil, cultivated and uncultivated, were very similar except in two sampling sites, Avala and Barajevo, wherein the soil sample were collected in forest areas.

Measured specific activity of ${ }^{238} \mathrm{U}$ in the soil samples did not show a significant increase in cultivated soil, indicating a low application of phosphorous fertilizers in crop production.

Further, there was no increase in specific activities of natural and artificial radionuclides in the vicinity of the Institute of Nuclear Sciences "Vinča" - these levels were similar to the results obtained for other locations. This finding could imply an insignificant impact of the activities undertaken in the nuclear institution on the surrounding environment.

Results of our work indicate that the natural environment of Belgrade is radioecologically safe and that food products from this region are safe for human consumption.

Acknowledgments: This paper is a part of the research done within the projects "Climate changes and their influence on the environment: impacts, adaptation and mitigation" (No. 43007) and "Development of technology and products based on mineral raw materials and biomass for protecting the food resources" (No. TR310o3) financed by the Ministry of Education, Science and Technological Development of the Republic of Serbia (2011-2016).

\section{REFERENCES}

1. A. Adel, M. Uosif and A. El-taher, "Natural radioactivity and dose assesment for phosphate rock from Wadi El-Mashash and El-Mahamid Mines, Egypt," J. Environ. Radioact., vol. 84, no. 1, pp. 6578, 2005.

2. M. Bolca, M. Sac, B. Cokuysal, T. Karali and E. Ekdal, "Radioactivity in soils and various foodstuffs from the Gediz river basin of Turkey," Radiat. Meas., vol. 42, no.2, pp. 263-270, 2007.

3. N. Vucic and Z. Ilic, "Extraction and spectrophotometric determination of uranium in phosphate fertilizers," J. Radioanal. Nucl. Chem., vol. 129, no. 1, pp. 113-120, 1989.

4. H. Hamamo, S. Landsberger, G. Harbotile and S. Panno, "Studies of radioactivity and heavy metals in phosphate fertlizer," J. Radioanal. Nucl. Chem., vol. 194, no. 2, pp. 331-336, 1995.

5. M. Nifontova, "Radionuclides in the moss/lichen cover of tundra communities in the Yamal
Peninsula," Sci. Total Environ., vol. 160-161, pp. 749$752,1995$.

6. R. Delfanti, C. Papucci and C. Benco, "Mosses as indicators of radioactivity deposition around a coalfired power station," Sci. Total Environ., vol. 227, pp. 49-56, 1999.

7. S. Dragović, O. Nedić, S. Stanković and G. Bačić, "Radiocesium accumulation in mosses from highlands of Serbia and Montenegro: chemical and physiological aspects," J. Environ. Radioact., vol. 77, no. 3, pp. 381-388, 2004.

8. United Nations Scientific Committee on the Effect of Atomic Radiation (UNSCEAR) 2008 Report to the General Assembly, with scientific annexes, Sources and effects of ionizing radiation, vol. II, United Nations, New York, US, 2011.

9. B. Mitrović, G. Vitorović, D. Vitorović, G. Pantelić and I. Adamović, "Natural and athropogenic radioactivity in the environment of mountain region of Serbia," J. Environ. Monitor., vol. 11, no. 2, pp. 383-388, 2009.

10. S. Grdović et al., "Natural and anthropogenic radioactivity of feedstuffs, mosses and soil in the Belgrade environment, Serbia," Arch. Biol. Sci., vol. 62, no. 2, pp. 301-307, 2010.

11. E. F. Elstner, R. Fink, W. Holl, E. Lengfelder and H. Ziegler, "Natural and Chernobyl-caused radioactivity in mushrooms, mosses and soil-samples of defined biotops in SW Bavaria," Oecologia, vol. 73, no. 4, pp. 553-558, 1987.

12. P. Mishev, A. Damyanova and L. Yurukova, "Mosses as biomonitors of airborne pollution in the northern part of Rila Mountain," in Observatoire de montagne de Moussala OM2, Institut de recherche nucléaire et d'énergie nucléaire, 1997, pp. 137-141.

13. A. H. Knight, W. M. Crooke and R. M. Inkson, "Cation-Exchange Capacites of Tissues of Higher and Lower Plants and their Related Uronic Acid Contents," Nature, vol. 192, pp. 142-143, 1961.

14. H. Hecht, "Uniweltbedingte Rückstände in tierischen Geweben," Fleischwirtschaft, vol. 70, pp. 1016-1028, 1990.

15. I. Bikit et al., "Radioactivity of the soil in Vojvodina (northern province of Serbia and Montenegro)," $J$. Environ. Radioact., vol. 78, no. 1, pp. 11-19, 2004.

16. United Nations Scientific Committee on the Effect of Atomic Radiation (UNSCEAR), Report to the General Assembly, with scientific annexes, Sources and effects of ionizing radiation, United Nations, New York, US, 2000.

17. M. Papić et al., "Multi-criteria analysis of soil radioactivity in Čačak Basin, Serbia," Rom. J. Phys., vol. 59, pp. 846-861, 2014.

18. D. Popović and V. Spasić-Jokić, "Posledice nuklearne nesreće u Černobilju, na teritoriji Republike Srbije," Vojnosanit. Pregl., vol. 63, pp. 481-487, 2006.

19. Commission of the European Communities Report on Radiation Protection, Radioactivity measurement in Europe after the Chernobyl accident, Part 2. Fallout and deposition, Radiation protection, Commission of the European Communities, Brussels - Luxemburg, 1991.

20. J. B. Howard, A. N. Beresford and G. Voigt, "Countermeasures for animal products: a review of effectiveness and potential usefulness after an accident," J. Environ. Radioact., vol. 56, no. 1-2, pp. 115-137, January 2001.

21. S. Stanković, A. Stanković and G. Pantelić, "Prirodni i veštački radionuklidi u mahovinama sa različitih lokaliteta Srbije," Zbornik radova Naša ekološka istina $\mathrm{V}$ naučno stručni skup o prirodnim vrednostima i zaštiti životne sredine $X$ stručni sastanak preventivne medicine Timočke Krajine, Donji Milanovac, pp. 190-193, June 1997. 
B. Mitrović et al., Radioecological Investigation..., Rad. Applic., 2016, 1, 3, 199-203

22. A. Čučulović, D. Popović, R. Čučulović and J. Ajtić, "Natural radionuclides and ${ }^{137} \mathrm{Cs}$ in moss and lichen in Eastern Serbia," Nucl. Technol. Radiat., vol. 27,

24. P.G. Facelli, G. Ferri and G. Di Gurado, "Italy," Rev. no. 1, pp. 44-51, 2012.

23. A. Čučulović, M. Sabovljević, and D. Veselinović, "The activity concentrations of $40 \mathrm{~K},{ }^{226} \mathrm{Ra},{ }^{232} \mathrm{Th},{ }^{238} \mathrm{U}$ and 7Be in Eastern Serbia in the period 2000-2012," Arch. Biol. Sci., vol. 66, no. 2, pp. 691-700, 2014. 